\title{
Transport analysis of ozone enhancement in Southern Ontario during BAQS-Met
}

\author{
H. He ${ }^{1}$, D. W. Tarasick ${ }^{1}$, W. K. Hocking ${ }^{2}$, T. K. Carey-Smith ${ }^{3}$, Y. Rochon ${ }^{1}$, J. Zhang ${ }^{1}$, P. A. Makar ${ }^{1}$, M. Osman ${ }^{2}$,

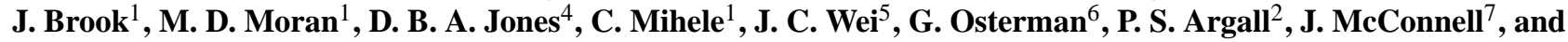 \\ M. S. Bourqui ${ }^{8}$ \\ ${ }^{1}$ Air Quality Research Division, Science and Technology Branch, Environment Canada, Downsview, ON, Canada \\ ${ }^{2}$ Department of Physics and Astronomy, University of Western Ontario, London, ON, Canada \\ ${ }^{3}$ National Institute of Water and Atmospheric Research Ltd., Private Bag 14901, Kilbirnie, Wellington, New Zealand \\ ${ }^{4}$ Department of Physics, University of Toronto, Toronto, ON, Canada \\ ${ }^{5}$ ADNET Systems, Inc., GES DISC 610.2, NASA GSFC, Greenbelt, MD, USA \\ ${ }^{6}$ Jet Propulsion Laboratory, NASA, Pasadena, CA, USA \\ ${ }^{7}$ Department of Earth and Space Science and Engineering, York University, Toronto, ON, Canada \\ ${ }^{8}$ Department of Chemistry and Atmospheric and Oceanic Sciences, McGill University, Montreal, QC, Canada
}

Received: 5 May 2010 - Published in Atmos. Chem. Phys. Discuss.: 24 June 2010

Revised: 13 January 2011 - Accepted: 2 March 2011 - Published: 18 March 2011

\begin{abstract}
Twice-daily ozonesondes were launched from Harrow, in southwestern Ontario, Canada, during the BAQSMet (Border Air Quality and Meteorology Study) field campaign in June and July of 2007. A co-located radar windprofiler measured tropopause height continuously. These data, in combination with continuous surface ozone measurements and geo-statistical interpolation of satellite ozone observations, present a consistent picture and indicate that a number of significant ozone enhancements in the troposphere were observed that were the result of stratospheric intrusion events. The combined observations have also been compared with results from two Environment Canada numerical models, the operational weather prediction model GEM (as input to FLEXPART), and a new version of the regional air quality model AURAMS, in order to examine the ability of these models to accurately represent sporadic crosstropopause ozone transport events. The models appear to reproduce intrusion events with some skill, implying that GEM dynamics (which also drive AURAMS) are able to represent such events well. There are important differences in the quantitative comparison, however; in particular, the poor vertical resolution of AURAMS around the tropopause causes it to bring down too much ozone in individual intrusions.
\end{abstract}

Correspondence to: $\mathrm{H} . \mathrm{He}$

(huixia.he@ec.gc.ca)
These campaign results imply that stratospheric intrusions are important to the ozone budget of the mid-latitude troposphere, and appear to be responsible for much of the variability of ozone in the free troposphere. GEM-FLEXPART calculations indicate that stratospheric ozone intrusions contributed significantly to surface ozone on several occasions during the BAQS-Met campaign, and made a moderate but significant contribution to the overall tropospheric ozone budget.

\section{Introduction}

The Border Air-Quality and Meteorology Study (BAQSMet) was conducted in the Great Lakes region of southwestern Ontario in the summer of 2007 in part to study the impact of the transborder flow of pollutants and long-range transport on local air quality, especially the high levels of air pollutants that frequently and episodically occur in this area. A particular focus of the field study was evaluation of the ability of the Environment Canada AURAMS chemical transport model (CTM) to represent regional air pollution in southwestern Ontario, near the US-Canada border.

Previous versions of the AURAMS CTM had large negative biases in the free troposphere for ozone, owing to inadequate treatment of model domain boundaries, including the upper boundary (Tarasick et al., 2007). For the BAQS-Met

Published by Copernicus Publications on behalf of the European Geosciences Union. 
study a new version of the AURAMS CTM was employed, with climatological (Logan, 1999) values of ozone in the stratosphere and a realistic tropopause from the Canadian operational weather forecast model, GEM (Global Environmental Multiscale model: Côté et al., 1998) that is used to drive the AURAMS CTM. The performance of this model against observations, and with respect to several variations of top and lateral climatological boundary conditions, is examined in detail elsewhere in this issue (Makar et al., 2010a, b).

A number of studies have shown that mean tropospheric ozone fields in regional air quality models are sensitive to the top boundary condition (Tong and Mauzerall, 2006; Tarasick et al., 2007; Tang et al., 2007), and the stratosphere is generally believed to be a significant source of ozone in the troposphere (e.g., Stevenson et al., 2006). Although the global flux of ozone from the stratosphere is controlled non-locally, by the global circulation, it is episodic, being associated with tropospheric weather systems, and varies both spatially and with season (Holton et al., 1995). Stratosphere-troposphere exchange events are most common at midlatitudes (Singh et al., 1980; Appenzeller and Davies, 1992; Beekmann et al., 1997; Sprenger and Wernli, 2003).

Numerous case studies have shown that individual crosstropopause ozone transport events can affect tropospheric ozone levels, even down to the surface (e.g., Bourqui and Trepanier, 2010; Lefohn et al., 2001; Elbern et al., 1997; Davies and Schuepbach, 1994; Wakamatsu et al., 1989; Oltmans et al., 1989). However, the overall importance of stratospheric ozone intrusions to the tropospheric ozone budget depends on their distribution with geography and season, and on the fate of the exchanged air parcels, particularly their vertical penetration and residence time (Stohl et al., 2003; Cooper et al., 2004; Thompson et al. 2007; Tarasick and Slater, 2008). For these reasons, at least in part, observational estimates of the stratospheric contribution vary widely (e.g., Bachmeier et al., 1994; Browell et al., 1994, 2003; Mauzerall et al., 1996; Dibb et al., 1994, 1997, 2003; Allen et al., 2003; Bazhanov and Rodhe, 1997; Elbern et al., 1997; Li et al., 2002; Cooper et al., 2006; Thompson et al. 2007).

Although cross-tropopause ozone transport is clearly sporadic, it is not clear to what extent stratospheric intrusions contribute to the variability of ozone in the free troposphere, in comparison to other potential sources, such as photochemistry, convection, and differential horizontal advection. However, the fact that stratospheric contributions to the tropospheric ozone budget, and possibly to local air pollution episodes, are time- and location-dependent is evidently an issue of some importance to air quality forecast models. There have been few detailed comparisons of observations and models with the objective of examining how well these events are captured by current weather and air quality forecast models.
Balloon-born ozonesondes with fine vertical resolution $(\sim 100 \mathrm{~m})$ and with moderate temporal resolution have been used previously to study stratosphere-troposphere exchange (STE) during a number of field campaigns (Oltmans et al., 1989; Wakamatsu et al., 1989; Thompson et al., 2010). The primary challenge with using ozonesondes for studying stratospheric ozone intrusions is their limited coverage. Nadir-viewing satellite observations, in contrast, have limited vertical resolution but offer wide geographic coverage that can complement detailed profile information from ozonesondes.

This study presents observations of stratospheric ozone intrusions during a short summer campaign near Windsor, Ontario (latitude $42^{\circ} \mathrm{N}$ ), using measurements from ozonesondes, a radar windprofiler, in-situ surface ozone monitors, and the Tropospheric Emission Spectrometer (TES) and Atmospheric Infrared Sounder (AIRS) satellite instruments. These are compared with model results from the Lagrangian particle dispersion model FLEXPART (Stohl et al., 2005), driven by GEM meteorological fields, and from the new AURAMS CTM, and used to examine the ability of these models to accurately represent sporadic cross-tropopause ozone transport events.

\section{Data, models, and methods}

\subsection{Campaign data}

The BAQS-Met study was a measurement-intensive field campaign, conducted from 20 June to 10 July 2007, in the region bounded by Lakes Huron, St. Clair, and Erie in southernmost Canada. Here we focus on data from one site, Harrow, Ontario $\left(42.03^{\circ} \mathrm{N}, 82.92^{\circ} \mathrm{W}\right)$.

During the campaign, ozonesondes were released every $12 \mathrm{~h}$ (at 00:00 and 12:00 UTC) at Harrow from 20 June to 7 July. However, since 1 July is a national holiday in Canada, no releases were made on 1 and 2 July (a choice which proved unfortunate, as described below). In total, 23 successful launches were made. The instruments used in the study were GPS-equipped EN-SCI model 2Z-ECC ozonesondes and Vaisala RS80 radiosondes. They provide vertical profiles of ozone concentration, temperature, humidity, and wind speed and direction from the ground to the stratosphere. The ozone sensors have a precision of 3-5\% and an absolute accuracy of about $10 \%$ in the troposphere, with a vertical resolution of about $100 \mathrm{~m}$ (Smit et al., 2007). The data are available from the World Ozone and UV Radiation Data Centre (www.woudc.org).

A Wind-Turbulence tracker (WindTtracker) windprofiler radar that is located at Harrow close to the ozonesonde site provided hourly measurements of tropopause height. The radar-derived tropopause height is defined as the altitude between 6 and $14 \mathrm{~km}$ where the secondary maximum value of backscattered power (if present) occurs. It shows good 
agreement with the thermal tropopause (Gage et al., 1986; Vaughan et al., 1995; Hocking, 1997; Hooper and Arvelius, 2000).

Continuous measurements of surface ozone reported as one-minute averages were also made at Harrow throughout the BAQS-Met campaign, using a Thermo Scientific model $49 \mathrm{c}$ ozone analyzer. These measurements have uncertainties less than 3\% (Williams et al., 2006). Data were obtained from http://caredata.tor.ec.gc.ca.

The Tropospheric Emission Spectrometer (TES) on the NASA Aura satellite is an infrared, high-resolution Fourier transform spectrometer that provides vertical profiles of tropospheric ozone and other atmospheric constituents (Beer et al., 2001; Beer, 2006). TES constituent vertical profiles are retrieved by an optimal method (Osterman, 2004; Worden et al., 2004; Kulawik et al., 2006). Here we use Version 3 (V003) TES Level 2 global survey data, obtained from the NASA Langley Atmospheric Science Data Center (http://eosweb.larc.nasa.gov/HPDOCS/datapool). The data have an observation footprint of 5 by $8 \mathrm{~km}$, but successive observations are about $0.86^{\circ}$ apart in latitude and $1.5^{\circ}$ in longitude (TES does not perform cross-track scanning). Compared to ozonesondes, TES ozone profiles show a 5-15\% high bias in the troposphere (Nassar et al., 2008; Boxe et al., 2010). During the BAQS-Met campaign, for observations close to Harrow, TES averaging kernels exhibit a mean of 1.24 degrees-of-freedom (DOF) for signals in the troposphere, indicating that TES is able to resolve middle and upper tropospheric ozone. (The DOF is the trace of the averaging kernel matrix and gives the number of vertically independent pieces of information in the measurement.) Figure 1 shows the averaging kernels of the TES observation closest to Harrow from a two-day global survey on 30 June and 1 July 2007. The DOF of this profile within the troposphere is 1.49. Figure 1 also indicates that some of the averaging kernels show peak sensitivity in the lower troposphere and even as low as $900 \mathrm{hPa}$, indicating (e.g., Worden et al., 2007) that (for this profile) TES has sensitivity to boundary-layer ozone.

The Atmospheric Infrared Sounder (AIRS), on the NASA Aqua satellite, provides profiles of atmospheric temperature, water vapour, and a number of trace gas species including ozone, using a nadir cross-track scanning infrared instrument with a $15-\mathrm{km}$ field of view (Fetzer et al., 2006). Here we use Version 5 (V005) of the AIRS standard level 2 ozone products (Olsen et al., 2007a, b), obtained from the Goddard Earth Sciences (GES) Data Information and Services Center (http://disc.sci.gsfc.nasa.gov/AIRS/ data-holdings/by-data-product/data_products.shtml). The data have an observation footprint of $45 \mathrm{~km}$ by $45 \mathrm{~km}$, but successive pixels overlap so that complete coverage at midlatitudes is obtained daily. Compared to ozonesondes, AIRS version 5 data show a high bias in the upper troposphere and a low bias in the lower stratosphere, at mid-and high latitudes (Bian et al., 2007; Monahan et al., 2007; Divakarla et al.,

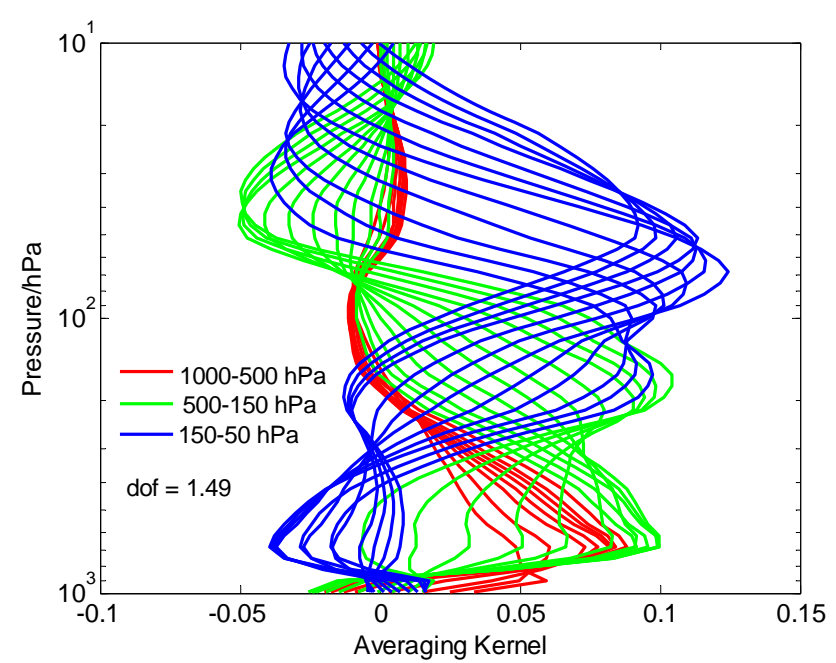

Fig. 1. Averaging kernels of TES signals in a two-day global survey (on 30 June and 1 July 2007).

2008). This bias is similar but marginally higher than that of TES. The DOFs of AIRS observations within the troposphere are less than 1, so AIRS offers less information about the vertical distribution of ozone in the troposphere than TES, but the much better latitude-longitude coverage makes AIRS ozone and water vapour profiles a useful complement to the TES data for detecting stratospheric ozone intrusions.

\subsection{Models}

AURAMS (A Unified Regional Air-quality Modelling System, version 1.4.0) consists of three main components: (a) a prognostic meteorological model, GEM (Global Environmental Multiscale model; Côté et al., 1998); (b) an emissions processing system, SMOKE (Sparse Matrix Operator Kernel Emissions; Houyoux et al., 2000; CEP, 2003); and (c) an offline regional chemical transport model, the AURAMS CTM (e.g., Gong et al., 2006; Cho et al., 2009; Makar et al., 2009; Smyth et al., 2009). For the BAQS-Met simulations, GEM version 3.2.2 with physics version 4.5 was run on a variableresolution, global, horizontal rotated latitude-longitude grid with a uniform core grid covering North America $(575 \times 641$ grid points over the globe, with $432 \times 565$ grid points over North America, $0.1375^{\circ}$ or approximately $15.3 \mathrm{~km}$ grid spacing in the core region, $450 \mathrm{~s}$ time step) and 58 vertical levels up to $10 \mathrm{hPa}$.

The AURAMS CTM is a comprehensive multi-pollutant, regional tropospheric air quality model with gas-phase, aqueous-phase, and heterogeneous chemistry, and sizesegregated and chemically-speciated representation of aerosols. It does not have a comprehensive stratospheric chemistry package. For the BAQS-Met simulations considered here, three nested horizontal domains were used: an outer North American domain with $42 \mathrm{~km}$ horizontal grid 
spacing and $900 \mathrm{~s}$ time step, an intermediate eastern North American domain with $15 \mathrm{~km}$ horizontal grid spacing and 900 s time step, and an inner domain centred on southwestern Ontario with $2.5 \mathrm{~km}$ horizontal grid spacing and $120 \mathrm{~s}$ time step. For all three domains 28 vertical levels were used, with a spacing that varies from $15 \mathrm{~m}$ near the surface to $2.7 \mathrm{~km}$ at the model top, which is located at $18 \mathrm{~km}$ above ground level; half of the vertical levels are below $2 \mathrm{~km}$. Ozone boundary conditions for the outermost CTM domain were provided by the Logan (1999) climatology, linearly scaled above and below the tropopause every $900 \mathrm{~s}$ time step to match the climatological tropopause to the actual tropopause height determined by GEM (dynamic tropopause height adjustment). Above $100 \mathrm{hPa}$ (the top of the Logan climatology), ozone values were extrapolated (where necessary) to $50 \mathrm{hPa}$, assuming a constant gradient of mixing ratio. This configuration (with no sponge layer at the model top, and no mass consistency corrections) was found to provide the best overall performance throughout the troposphere (Makar et al., 2010b). The 42-km domain supplies ozone boundary conditions for the $15-\mathrm{km}$ domain, which in turn supplies them for the $2.5-\mathrm{km}$ domain.

The Lagrangian particle dispersion model FLEXPART (Stohl et al., 2005) has been extensively validated (Stohl et al., 1998, 2000; Cristofanelli et al., 2003; Meloen et al., 2003) and frequently used to model stratospheric intrusions (Bonasoni et al., 2000; James et al., 2003a, b; Zanis et al., 2003; Cooper et al., 2004, 2005; Hocking et al., 2007). For the BAQS-Met study, FLEXPART was driven by hourly meteorological data generated by GEM version 3.2.2, on a uniform resolution global domain with $800 \times 600$ grid points over the globe $\left(0.45^{\circ}\right.$ longitude $\times 0.3^{\circ}$ latitude resolution $)$, with 58 vertical levels from the sea surface level to $10 \mathrm{hPa}$ and a $450 \mathrm{~s}$ time step. The use of a global domain, rather than the regional domain used for AURAMS, permitted a wider domain to be used for FLEXPART, for better capture of tropopausecrossing events far from Harrow. Both the regional GEM runs used for AURAMS and these global runs used the same initial conditions, which were provided by the archived 6-h meteorological analyses.

FLEXPART version 6.2 was run on a portion of the global GEM domain $\left(20-180^{\circ} \mathrm{W}, 30-90^{\circ} \mathrm{N}\right)$. This represents a choice between horizontal resolution and domain size, made necessary by limitations on the size of input files for FLEXPART. FLEXPART uses a domain-filling procedure where a large number of particles are released within the model domain at the beginning of a model run. The dynamic tropopause, defined using potential vorticity (PV), is used in FLEXPART to locate the surface that separates the stratospheric and tropospheric air masses. During model initialization, particles that are in the stratosphere (i.e., those having a potential vorticity greater than 2 PVU, where 1 $\mathrm{PVU}=10^{-6} \mathrm{~K} \mathrm{~m}^{2} \mathrm{~kg}^{-1} \mathrm{~s}^{-1}$ ), are tagged with an ozone concentration calculated using the relation $\mathrm{O}_{3}=\mathrm{S} \times \mathrm{PV}$, where $\mathrm{S}$ is a constant. Following Stohl et al. (2000), we used
$\mathrm{S}=60 \mathrm{ppbv} / \mathrm{PVU}$ for June and $51 \mathrm{ppbv} / \mathrm{PVU}$ for July. Particles originating in the troposphere, on the other hand, are tagged with an ozone concentration of zero. All of these particles are then advected using model wind fields. New particles are created and initialized in the same way on in-flow boundaries. FLEXPART does not include any chemistry and ozone is assumed to have an infinite lifetime once in the troposphere. This assumption is reasonable as none of the simulations went beyond 20 days, while the lifetime of ozone in the troposphere is typically 20-30 days (Stevenson et al., 2006). In addition, because of the limited domain size any particular particle is unlikely to stay within the domain for that length of time. However, this also means that particles that crossed from the stratosphere before entering the domain will have zero ozone concentration. In other words, only intrusions that occur within the domain are simulated. This is probably not a major issue since the domain is quite large. FLEXPART parameterizes convection using the scheme presented in Emanuel and Zivkovic-Rothman (1999) and Seibert et al. (2001), and parameterizes turbulence in the free troposphere and boundary layer by solving Langevin equations (Stohl and Thomson, 1999).

\subsection{Kriging interpolation of satellite data}

Since satellite data can not provide observations at specific positions on consecutive days, Kriging interpolation of TES and AIRS data was used to obtain approximate observations at the BAQS-Met study location. Kriging is a popular linear least-squares interpolation method widely used in mining, mapping, hydrogeology, and environmental science, (e.g., Bayraktar and Sezer Turalioglu, 2005), as well as remote sensing (Stein et al., 2002; Tranchant and Vincent, 2000). Kriging considers the observations as a realization of a random spatial process. Ordinary Kriging, used here, allows one to construct an unbiased estimator that does not require the quantity of interest have a time-invariant probability distribution. The ordinary Kriging interpolation, $y\left(x_{0}\right)$ at a unobserved point $x_{0}$, is a weighted linear combination of all observations $y\left(x_{n}\right), n=1, \ldots, N$, i.e.,

$\hat{y}\left(x_{0}\right)=\sum_{n=1}^{M} \lambda_{n}\left(x_{0}\right) y\left(x_{n}\right)$

with $\sum_{n=1}^{M} \lambda_{n}\left(x_{0}\right)=1$. The weighting coefficients $l_{n}\left(x_{0}\right)$ for each interpolated location $x_{0}$ are determined from the semivariogram equations,

$\sum_{n=1}^{M} \lambda_{n}\left(x_{0}\right) r\left(x_{n}, x_{m}\right)+\mu=r\left(x_{m}, x_{0}\right), \quad m=1, \ldots, \mathrm{N}$,

based on the minimum estimated variance criterion. The semi-variance $r=\left(x_{n}, x_{m}\right)$ is a function of the separation distances between observations, e.g., $r\left(x_{n}, x_{m}\right)=f\left(0.5|| x_{n}-\right.$ 


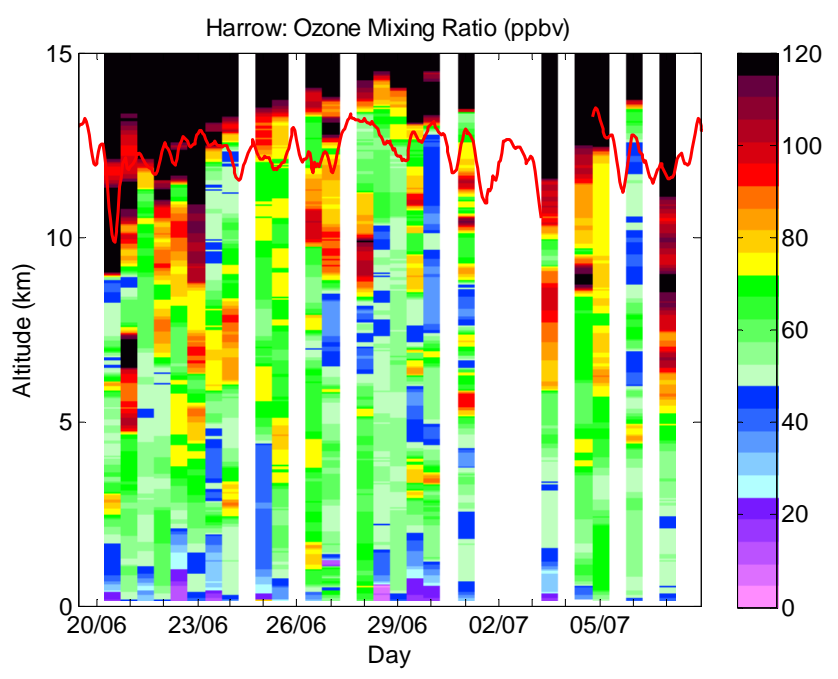

Fig. 2. Vertical profiles of ozone mixing ratio (ppbv) for the BAQSMet campaign at Harrow, Ontario, in the summer of 2007. The red solid line shows the tropopause height derived from the radar data. Date and time are UTC.

$\left.x_{m} \|^{2}\right)$ where $\left\|x_{n}-x_{m}\right\|^{2}$ is the square of the Euclidean distance between two locations $x_{n}$ and $x_{m}$, and the unknown constant $\mu$ is determined by the minimization. The experimental semi-variogram is estimated from scattered locations and observations, and the model semi-variogram $f$ is usually a Gaussian, spherical, or exponential function that fits the shape of the experimental variogram. Here we use a simple exponential function.

\section{Observations and model results}

\subsection{Ozonesondes}

Figure 2 shows ozone volume mixing ratios in parts per billion volume (ppbv) as a function of height and time, from all the ozonesonde flights during the BAQS-Met campaign. Launch times and time for all other observations and model simulation results are displayed in Universal Time (UTC), which is five hours ahead of local standard time. Each ozonesonde launch is represented by a vertical column of coloured boxes, with the time rounded to the nearest half day. Radar-derived tropopause heights (at about 9.5-13.5 km) are shown by the red solid line.

Several enhancements of ozone in the upper troposphere (typically $80 \mathrm{ppbv}$ or more) appear in this ozonesonde "curtain plot". Particularly evident are those on 20 June, 22-24 June, 26-28 June, and 3, 4 and 7 July. The enhancements in June also show an apparent descent from left to right; that is, with time. This is less evident with the July enhancements, perhaps because of missing data. Examination of relative humidity profiles (not shown) shows in general low relative humidity coincident with the ozone enhancements, indica-

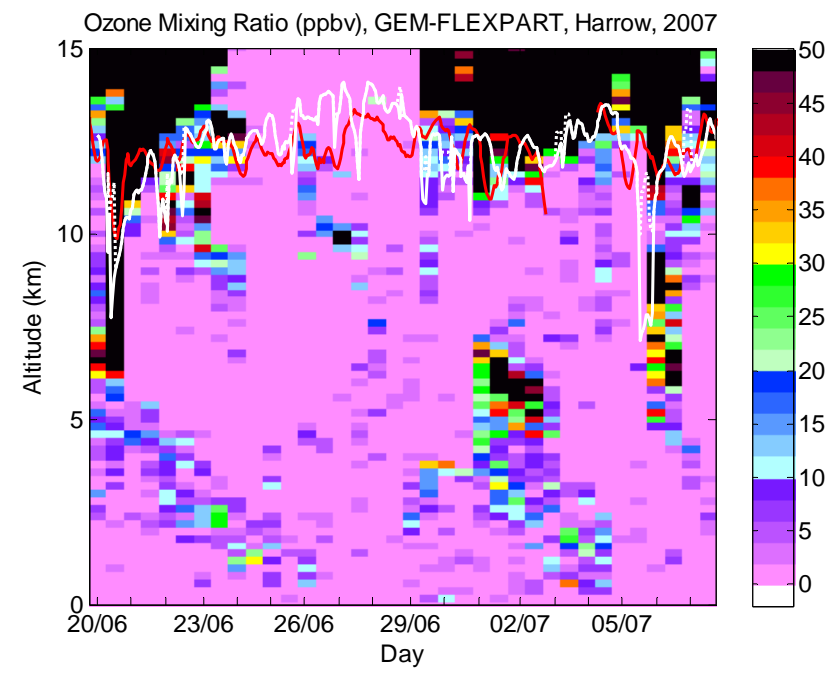

Fig. 3. Vertical profiles of ozone mixing ratios from a GEMFLEXPART simulation, at the location of the Harrow site in the summer of 2007. The red solid line shows the tropopause height derived from the radar data, and the white lines (solid and dashed) show the (first and second) tropopauses derived from the potential vorticity distribution estimated in the GEM model. Date and time are UTC.

tive of a stratospheric origin. The radar tropopause height, also indicated in Fig. 2, shows a large and rapid increase on 20 June, and modest but also rapid increases on 30 June and 5 July. Hocking et al. (2007) found that rapid increases of (radar-determined) tropopause height were a good predictor of stratospheric intrusions. A larger increase on 27 June is less rapid, and does not appear to be associated with an ozone enhancement. The apparent intrusion on 26-27 June is not preceded by a major tropopause change, although it may be related to a smaller increase on 25 June. Ozonesonde data are unfortunately not available on 1-2 July, and radar data are not available for a portion of 3-4 July.

\subsection{GEM-FLEXPART and AURAMS}

Figure 3 shows a similar curtain plot of ozone mixing ratios from a GEM-FLEXPART simulation, at Harrow, Ontario, from 20 June to 7 July 2007. The color scale is different from that of the ozonesonde observations in Fig. 2, since the FLEXPART model has been set up to simulate the transport and dispersion of a stratospheric ozone tracer and has no tropospheric background ozone.

The quantitative agreement between the ozonesonde observations and the GEM-FLEXPART simulation is poor, with the simulation producing concentrations that are much lower than the observations. This partly due to the lack of tropospheric sources of ozone in the model simulation. However, some similarity between Figs. 2 and 3 is evident, and suggests that the GEM model is reproducing the dynamics of stratospheric intrusion events and their subsequent 


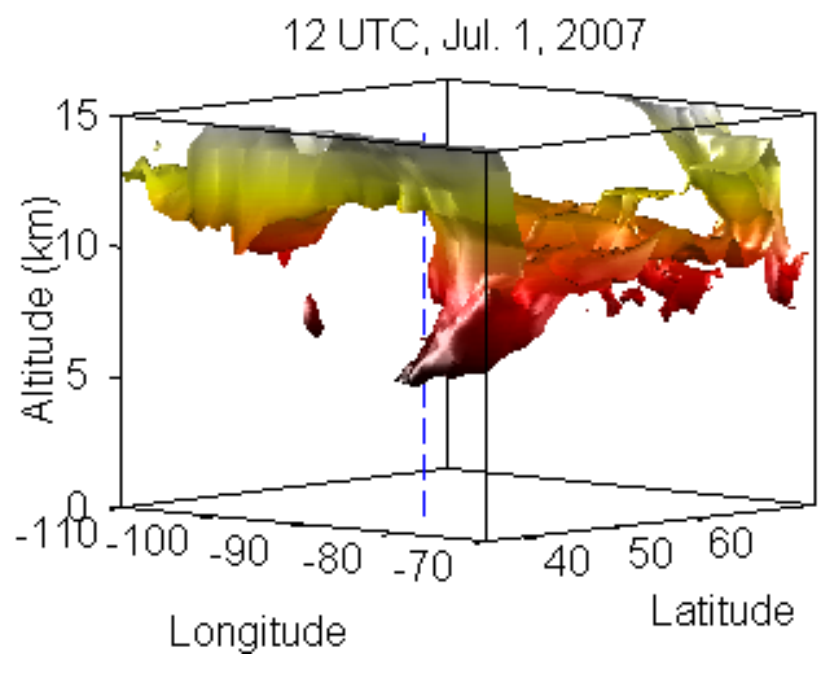

Fig. 4. GEM-FLEXPART results showing the 80 ppbv ozone mixing ratio isosurface at 12:00 UTC on 1st July 2007. The blue dashed line shows the location of Harrow. Darker colours indicate lower isosurfaces.

tropospheric evolution with some skill. The apparent intrusions on 20 June, 22-24 June, 26-28 June, 4 and 7 July can all be seen in the FLEXPART simulation, providing a very strong argument that they are of stratospheric origin. Detailed examination of individual profiles shows that many other prominent features in the sonde curtain are matched in the FLEXPART simulation: for example, the peaks at 4, 9 and $11 \mathrm{~km}$ on 29 June (but not that at $6 \mathrm{~km}$ ), and the peak at $9 \mathrm{~km}$ on 4 July. Other features show less agreement: the descent of ozone below $5 \mathrm{~km}$ from the 20 June intrusion, visible in the FLEXPART simulation from 20-26 June, is less evident in the sonde curtain, whereas the ozone injected on 22 June appears, in the sonde curtain plot, to be more significant, and to descend more rapidly, than the FLEXPART simulation suggests. The large intrusion on 7 July appears in the observations 12 hours later than in the FLEXPART plot. Nevertheless, major features and the overall pattern of variability in the sonde curtain are reproduced in the FLEXPART curtain.

Figure 3 also indicates a large event on 1-2 July, comprising a deep influx of ozone from the stratosphere resulting in high ozone penetrating to about $3 \mathrm{~km}$ altitude over Harrow on 1 and 2 July, with subsequent descent on 3 July and 4 . Unfortunately, as noted previously, there were no ozone soundings on 1 and 2 July (local time). The GEM-FLEXPART model results, however, show a tongue of ozone originating primarily from the stratosphere over Nunavut and the Northwest Territories (Fig. 4). Indeed, as this event appears in Fig. 3 to be completely disconnected from the stratosphere, the tropopause crossing must not have occurred over Harrow, but elsewhere. As noted, a rapid but modest increase in the radar tropopause height was observed on 30 June. That the source of the high ozone was apparently the stratosphere over the Arctic could explain why the radar did not show a larger tropopause height change. Meteorological charts show a broad but deep trough, centred over Hudson Bay on 28 June, moving slowly over northeastern Canada, to be centred over Labrador on 1 July (Fig. 5). Such a feature is commonly associated with STE (e.g., Johnson and Viezee, 1981), but it appears to have been too far north to strongly affect tropopause heights over Harrow.

As in the previous figure, the red solid line shows the radar tropopause. The white lines (solid and dashed) in Fig. 3 show the first, and where it exists, the second dynamic tropopause ( $P V=2$ PVU), used by FLEXPART, and calculated using meteorological data from GEM. The dynamic tropopause is expected to agree well with the thermal tropopause, except in regions of significant mixing of tropospheric and stratospheric air (Pan et al., 2007, and references therein). In Fig. 3, the dynamic tropopause height does agree well with the radar tropopause height, and in general changes in the former appear to follow those in the latter. Variability in the dynamic tropopause is higher, however, with many sharp negative excursions of height, typically where FLEXPART indicates stratospheric intrusions. The presence of a second dynamic tropopause also seems to be associated with a stratospheric intrusion - not surprisingly, since this may indicate a tropopause fold. This is most evident for the events of 20 June and 6 July. However, the largest rapid change in the dynamic tropopause height occurs on 27 June, and does not appear to be associated with a stratospheric intrusion.

Turning to the AURAMS model results, shown as a curtain plot in Fig. 6, it is clear that AURAMS is also capable of reproducing the major stratospheric ozone intrusion events seen in Figs. 2 and 3. The scale here is the same as for the ozonesonde curtain plot (Fig. 2), as AURAMS includes full tropospheric chemistry. The most striking feature about the comparison is the similarity of the high ozone concentration features on several days (20 June, 1-2 July, and 6 July). However, many of the smaller features seen in Figs. 2 and 3 do not appear, and there is a high ozone feature on 29-30 June, centred at $5 \mathrm{~km}$, that is not seen in the observations (although there is a feature at about $3.5 \mathrm{~km}$, in both the ozonesonde and the FLEXPART ozone curtains, that is probably related). A dominant feature is the high ozone event near $5 \mathrm{~km}$ on $1-2$ July, missing from Fig. 2 presumably due to missing data.

\subsection{Satellite data: TES and AIRS}

The lack of ozone soundings in the 1-2 July period may be partially remedied with the use of satellite data. Satellite observations have limited vertical resolution but offer wide geographic and temporal coverage that can complement detailed profile information from ozonesondes. Satellite data have been used to detect tropopause folds (Wimmers and Moody, 2004). Recently, it was shown that TES data provide 


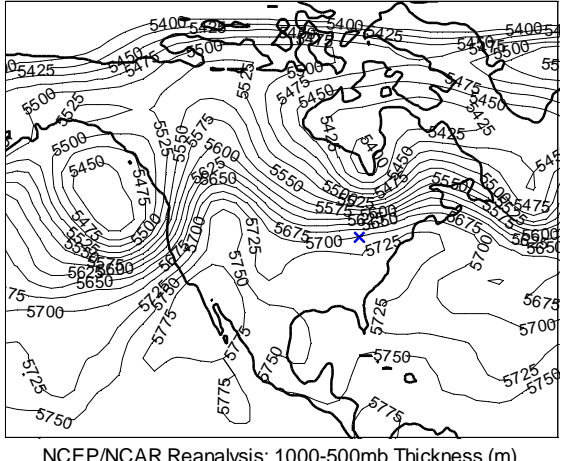

NCEP/NCAR Reanalysis; 1000-500mb Thickness (m) 12UTC 2007-06-28

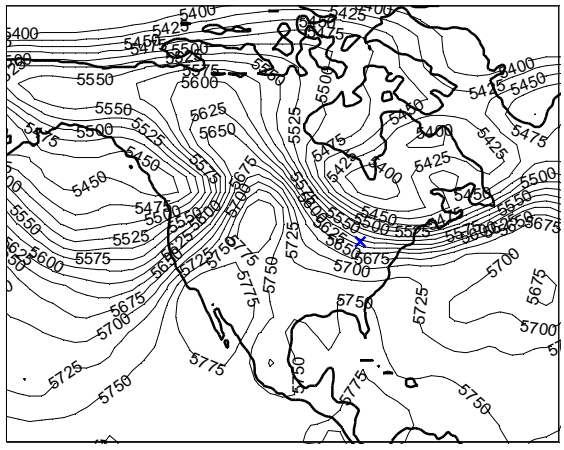

NCEP/NCAR Reanalysis; 1000-500mb Thickness (m) 12UTC 2007-06-30

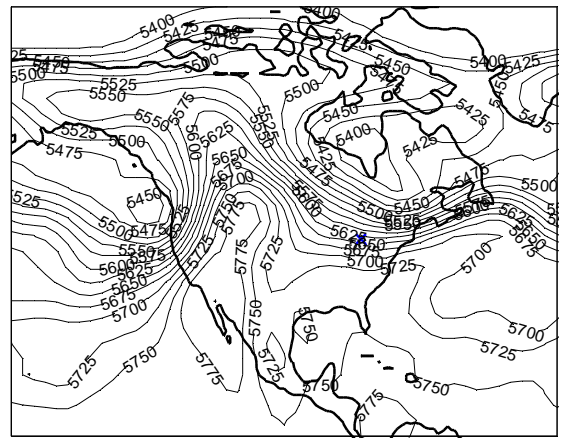

NCEP/NCAR Reanalysis; 1000-500mb Thickness (m) 12UTC 2007-06-29

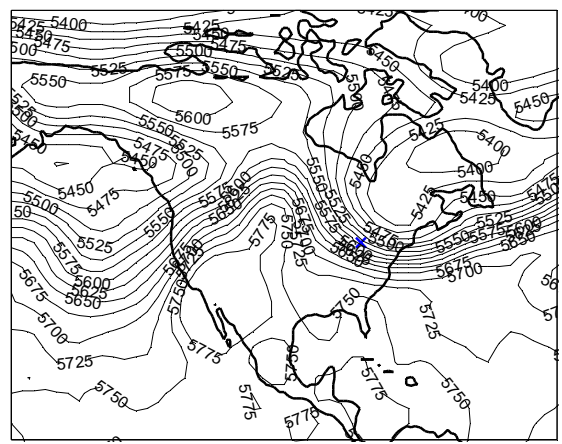

NCEP/NCAR Reanalysis; 1000-500mb Thickness (m)

Fig. 5. NCEP reanalysis showing $1000-500 \mathrm{hPa}$ thickness in metres for 28 June to 1 July 2007 at 12:00 UTC. The location of the Harrow site is shown by a blue cross.

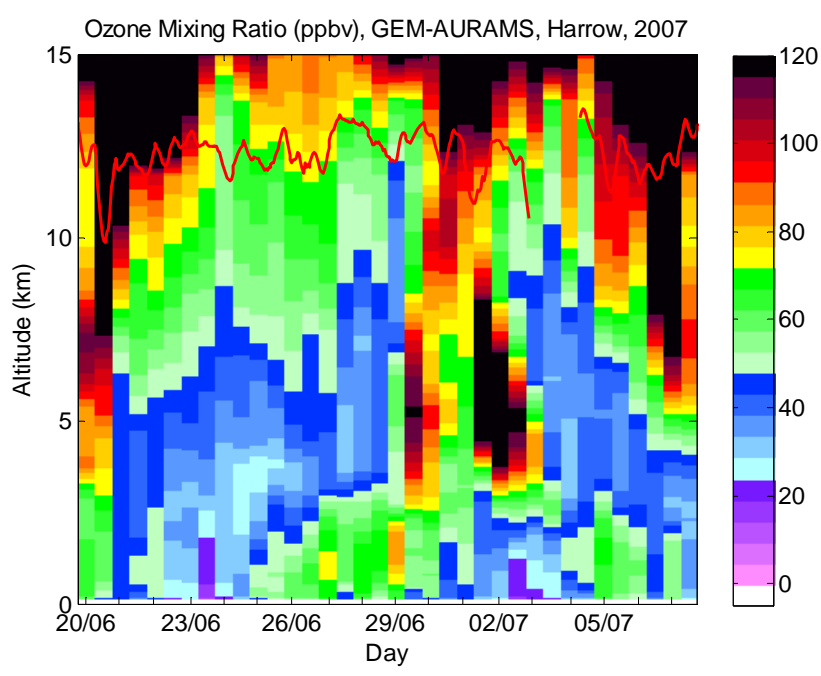

Fig. 6. Vertical ozone profiles from GEM-AURAMS, at Harrow during the BAQS-Met campaign. The red solid line shows the radarderived tropopause. Date and time are UTC.

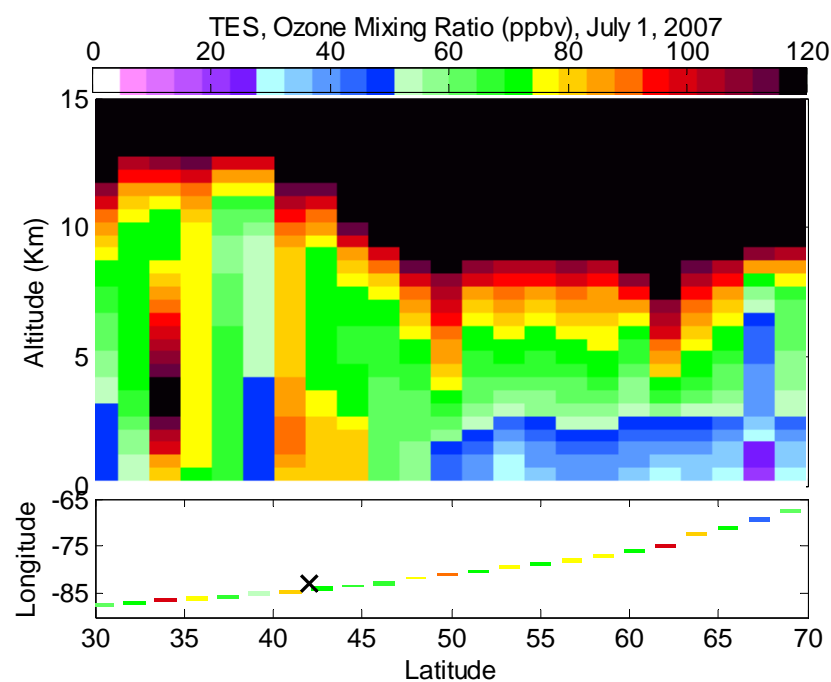

Fig. 7. Upper panel: vertical profiles of TES ozone mixing ratio (ppbv) along a global survey track (shown in the lower plot), on 1 July 2007. Lower panel: TES ozone mixing ratio (ppbv) at $6 \mathrm{~km}$ a.s.l. The black cross shows the location of Harrow. 

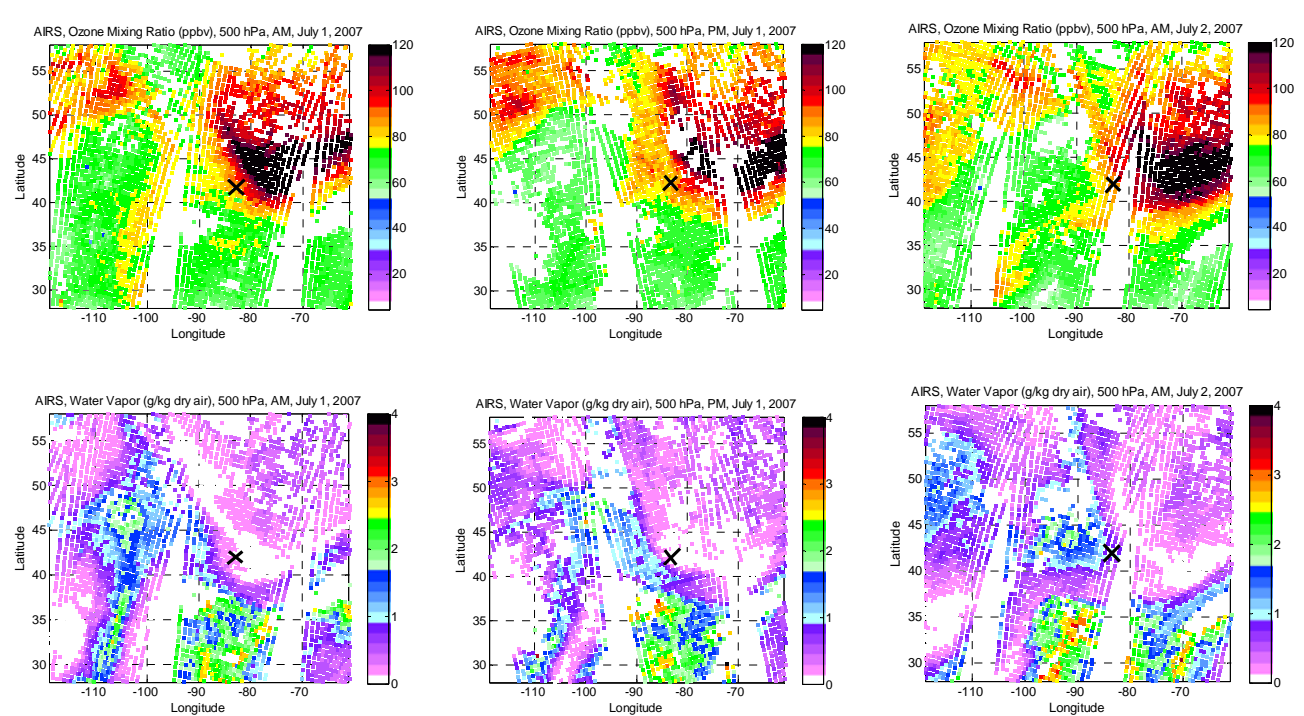

Fig. 8. AIRS observations at $500 \mathrm{hPa}(\sim 5.5 \mathrm{~km}$ a.s.1.) on 1-2 July 2007. Upper plots: ozone mixing ratio (ppbv); lower plots: water vapour mixing ratio $(\mathrm{g} / \mathrm{kg}$ dry air). The black cross shows the location of Harrow.

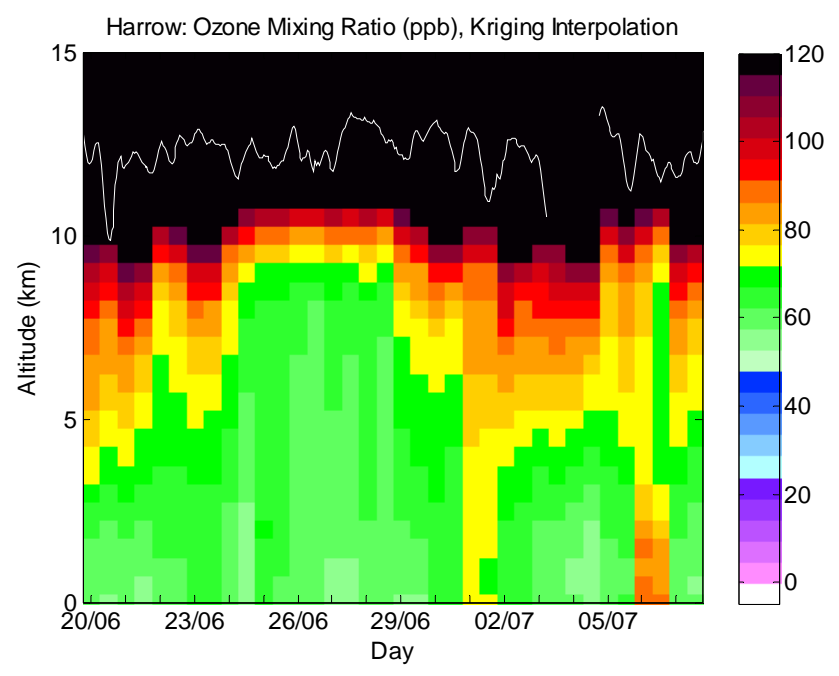

Fig. 9. Kriging interpolation results at Harrow, Ontario $\left(42.03^{\circ} \mathrm{N}\right.$, $\left.82.92^{\circ} \mathrm{W}\right)$, using TES and AIRS ozone profiles. The white solid line shows the tropopause height derived from the radar data. Date and time are UTC.

height-resolved information on STE events (Parrington et al., 2008). The upper panel of Fig. 7 shows a curtain plot of vertical profiles of ozone mixing ratio (ppbv) from TES, along a global survey track on 1 July 2007. The global survey track is shown in the lower panel. Close to the Harrow station (shown by a black cross), a profile with ozone enhancement (over $80 \mathrm{ppbv}$ ) throughout the troposphere is observed. This profile also appears to show high ozone in the boundary layer. The curtain plot also shows what appears to be a large trough, with ozone amounts typical of the stratosphere, in the upper troposphere and down to about $5 \mathrm{~km}$ altitude, to the north and east of Harrow. This is coincident with the feature shown in Fig. 5. On 2 July, there is no TES global survey data close to the Harrow station.

Figure 8 shows the same feature, observed by AIRS. The upper plots in Fig. 8 display the AIRS ozone at $500 \mathrm{hPa}$, ( $\sim 5 \mathrm{~km}$ altitude) on 1-2 July. An air mass rich in ozone $(\sim 100 \mathrm{ppbv})$ was located initially to the northeast of Harrow, and moved slowly eastward. This is coincident with the trough at $500 \mathrm{hPa}$ shown in Fig. 5, and in the TES profiles of Fig. 7. Low water vapour values coincident with the high ozone concentrations are further evidence of their stratospheric origin. Although TES profiles have less than 2 degrees of freedom in the troposphere, and AIRS less than 1, they are independent measurements, and a useful result may be obtained by combining them. Figure 9 shows the result of a Kriging interpolation of TES and AIRS ozone data at Harrow. No correction has been made for the known high biases of the satellite instruments. Since ozone observations in the troposphere have little correlation if their horizontal distance is greater than $600-1000 \mathrm{~km}$ (Liu et al., 2009), only TES and AIRS ozone profiles less than $1000 \mathrm{~km}$ from Harrow are used for the interpolation. The resulting curtain plot shows features that are broadly consistent with those of Fig. 2: on 20 and 21 June, high ozone concentration values (about $80 \mathrm{ppbv}$ ) down to an altitude of about $5 \mathrm{~km}$, high ozone in the upper troposphere on 22-24 June, generally lower ozone in the upper troposphere from 25-30 June, and an apparent deep intrusion on 6-7 July. These features are also quite consistent with the FLEXPART ozone curtain (Fig. 3). High ozone concentrations (approximately $80-100 \mathrm{ppbv}$ ) are also observed in the middle and lower troposphere on 1 July, consistent with the FLEXPART simulation, where there is a gap 
in the ozonesonde curtain (Fig. 2). On 6 July Fig. 9 shows high ozone in the lowest $2 \mathrm{~km}$ above the surface. Although TES retrievals occasionally produce anomalous high ozone values near the surface (Boxe et al., 2010), this is likely real, as averaging kernels for the 6 July profile are strongly peaked near $850 \mathrm{hPa}$, and the surface record shows high ozone in the boundary layer (over $75 \mathrm{ppbv}$ ) on that day.

\section{Discussion}

The AURAMS ozone curtain plot shows the same largerscale features as the FLEXPART curtain plot. This is not surprising as both are driven by the same meteorological model. They differ in smaller features, however. The general smoothness of the AURAMS curtain in the vertical is due to the comparatively coarse vertical resolution above $2 \mathrm{~km}$; this may also blur some of the features in the upper troposphere, such as the intrusions on 22-24 June and 26-28 June. Some other features are stronger, or shifted, however: the high ozone feature on 29-30 June at $5 \mathrm{~km}$, already noted, and the intrusion on 7 July, that seemed to appear in the FLEXPART simulation $12 \mathrm{~h}$ too early, also appears here on the 7 th.

Ozone profiles at specific times are examined in more detail in Fig. 10. These figures show six-hour averaged profiles at Harrow from GEM-FLEXPART and AURAMS simulations, and where available, ozonesondes. Since ozone mixing ratios obtained from FLEXPART do not include tropospheric background ozone, they have been shifted by an arbitrary constant value of $50 \mathrm{ppbv}$ to make them more comparable to those calculated from AURAMS. Figure 10a-f shows a number of profiles at times when stratospheric ozone intruded into the free troposphere. For the ozone intrusion events on 20 June and 1 July (Fig. 10a and b), the correspondence of AURAMS and GEM-FLEXPART is good, but AURAMS is clearly bringing down much more ozone: the intrusion is larger both in its peak concentration and in depth of the intruded layer. In Fig. 10c, e, f, and h GEM-FLEXPART seems to do a better job than AURAMS of reproducing the variability of ozone in the free troposphere, although the enhanced concentration of ozone predicted by GEM-FLEXPART in Fig. 10c is about $2 \mathrm{~km}$ below the observed peak. AURAMS, however, appears to have missed this large event. On 29 June (Fig. 10e), the shape of the AURAMS ozone profile suggests a large ozone intrusion down to $4 \mathrm{~km}$, while the ozonesonde profile and GEM-FLEXPART show several smaller intruded layers. In this case it appears that AURAMS has aggregated these layers, and is again overestimating the amount of ozone brought down. These occurrences when AURAMS appears to either ignore or overestimate intrusions are very likely simply due to the model's coarse vertical resolution above $2 \mathrm{~km}$.

Figure 10d shows an ozone enhancement in AURAMS in the upper troposphere (between 5 to $10 \mathrm{~km}$ ) on 7 July that is more consistent with the ozonesonde measurement than the
GEM-FLEXPART profile. This appears to be the same intrusion that the GEM-FLEXPART simulation showed a day earlier (but which was not observed in the ozonesonde profile). These differences may be due in part to different definitions of tropopause height in the two models. AURAMS uses the thermal tropopause criterion (WMO, 1966), whereas FLEXPART uses the dynamic tropopause determined by PV values. The thermal tropopause in the AURAMS model is typically coincident with the radar tropopause; which is compared in Fig. 3 with the dynamic tropopause. Another, possibly more important difference is that FLEXPART uses PV as a proxy for ozone. Figure $10 \mathrm{~g}$ and $\mathrm{h}$ shows cases where significant stratospheric influence was absent. The AURAMS simulation has generated ozone in the boundary layer by photochemical reactions, but it appears to have a significant negative bias in the lower troposphere above the boundary layer.

Figure 11 displays one-minute averages of surface ozone volume mixing ratios from the surface monitor at Harrow, bias-corrected GEM-FLEXPART ozone mixing ratios at the lowest level (190 m above sea level, which at Harrow is ground level), and GEM-AURAMS ozone mixing ratios at $190 \mathrm{~m}$ a.s.l. Ozone mixing ratios from ozonesonde measurements at the ground level are also shown. Estimates from the AURAMS simulation agree with the surface ozone and ozonesonde observations very well. GEM-FLEXPART results indicate that stratospheric ozone intrusions contributed significantly to surface ozone on 26, 29-30 June and 1 July.

It is possible to use FLEXPART to estimate the overall fraction of tropospheric ozone that is of stratospheric origin. The ozone mixing ratios from the GEM-FLEXPART simulations were corrected by comparing to ozonesonde measurements in the stratosphere, using the mean value of modeled/measured ratios over the entire campaign period. Comparing these bias-corrected GEM-FLEXPART profiles with the actual ozonesonde measurements, one can estimate the fraction of ozone at any point that is of stratospheric origin. In this manner we find that averaged over the BAQS-Met campaign, about $26 \%$ ozone in the upper/middle troposphere ( $3 \mathrm{~km}$ up to the tropopause), about $10 \%$ of ozone between $1 \mathrm{~km}$ and $3 \mathrm{~km}$, and about $8 \%$ of ozone in the boundary layer (less than $1 \mathrm{~km}$ ) was of stratospheric origin. These estimates of the stratospheric contribution to mid-tropospheric ozone are comparable to those of Colette and Ancellet (2005) using long-term ozonesonde records over Europe, and of Cooper et al. (2006) and Thompson et al. (2007) for the 2004 IONS summer campaign over North America, and suggest that stratospheric ozone made a moderate but significant contribution to the tropospheric ozone budget.

\section{Conclusions}

Although stratospheric ozone intrusions are most often observed in winter and spring (e.g., Appenzeller et al., 1996; Moody et al., 1995; Sprenger and Wernli, 2003; Stevenson 


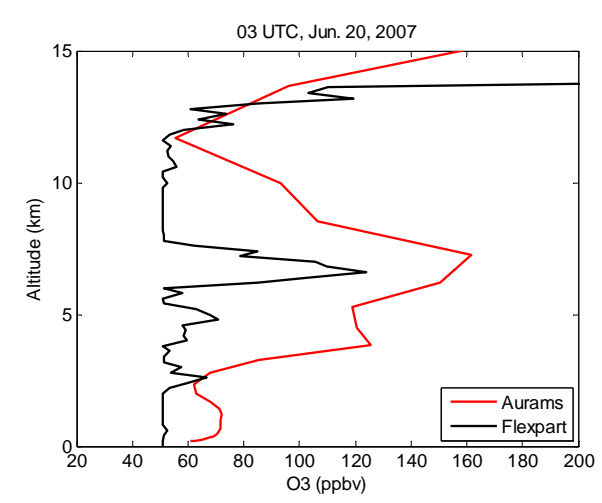

(a)

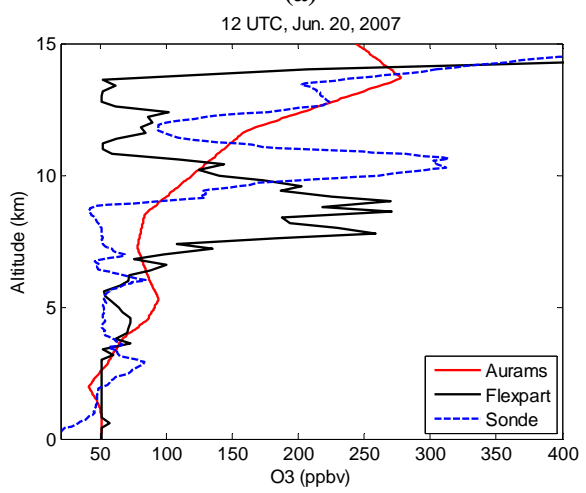

(c)

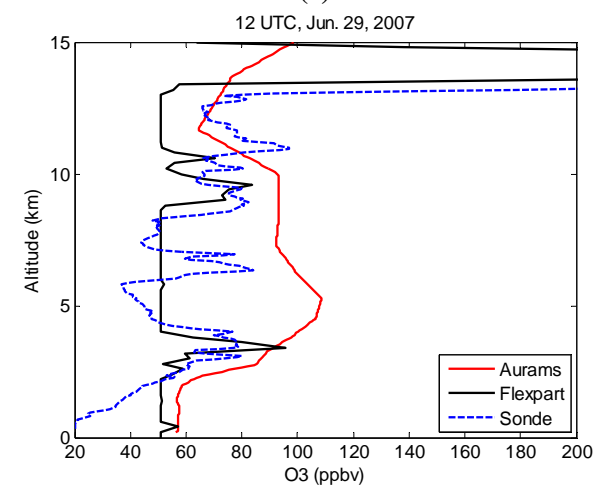

(e)

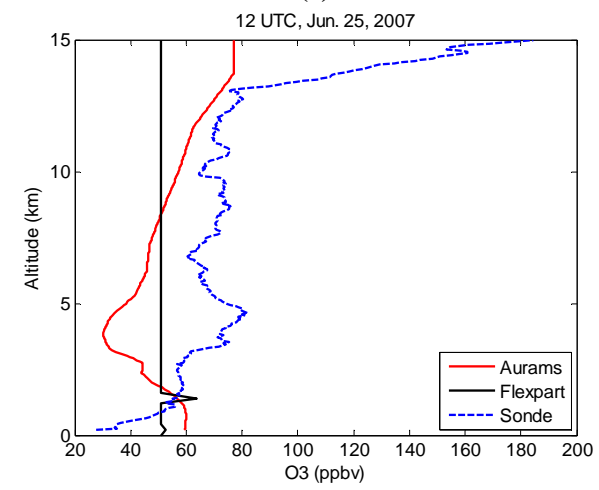

(g)

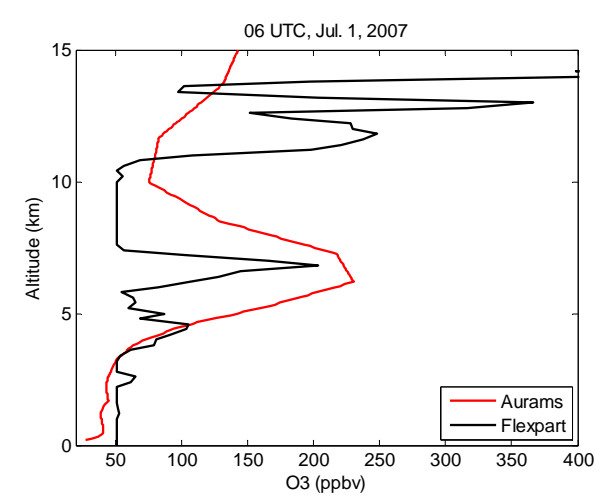

(b)

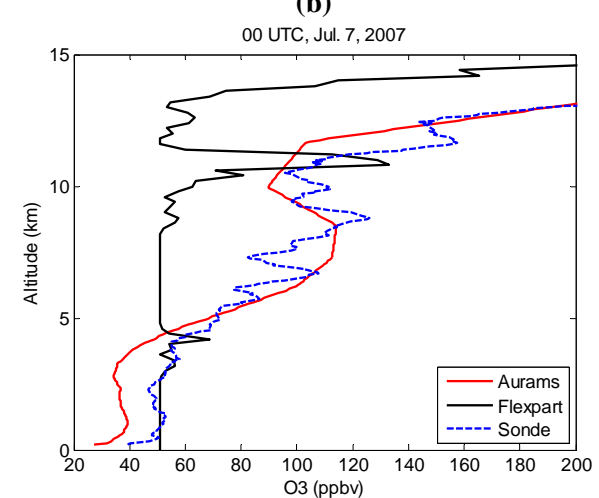

(d)

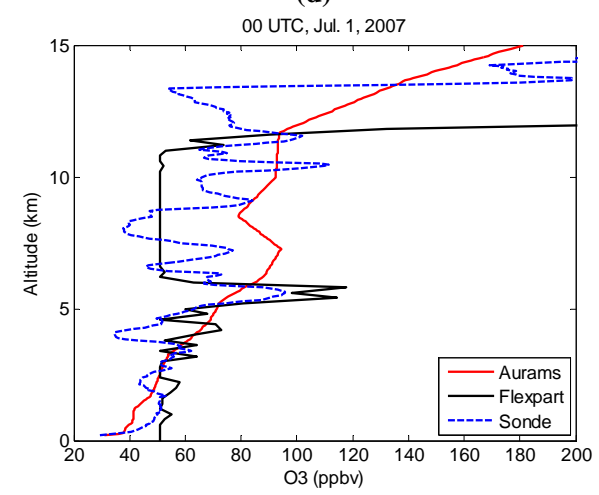

(f)

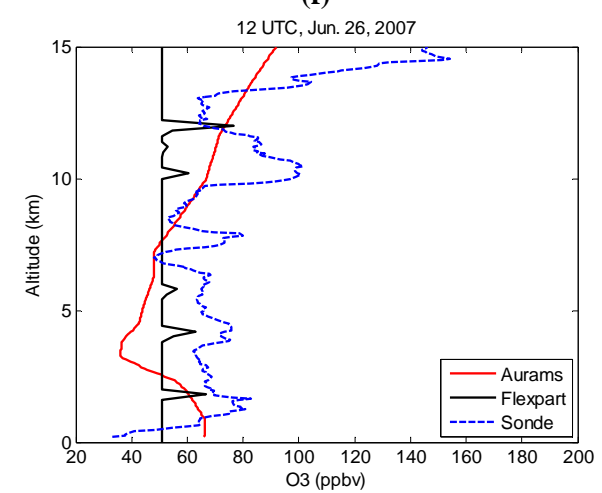

(h)

Fig. 10. Comparison of ozone profiles extracted from GEM-FLEXPART and GEM-AURAMS simulations for Harrow, and ozonesonde profiles. 


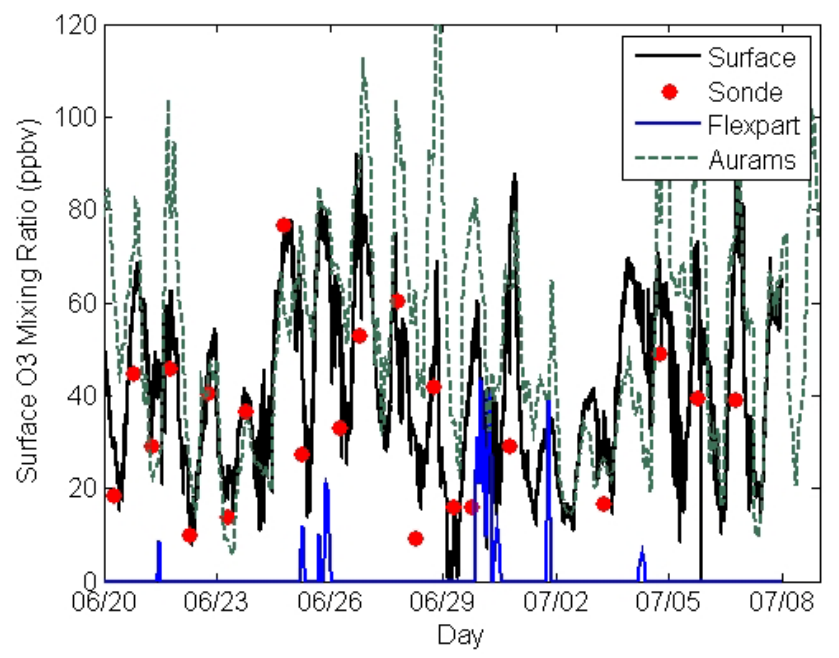

Fig. 11. Comparison of surface ozone mixing ratios (ppbv) at Harrow from observations and model simulations at ground level: surface ozone measurements (black line), ozonesonde observations at ground level (red dots), bias-corrected GEM-FLEXPART ozone mixing ratio at $190 \mathrm{~m}$ a.s.l. (blue line), and GEM-AURAMS ozone mixing ratio at $190 \mathrm{~m}$ a.s.l (green dashed line).

et al. 2006), they are also common summer events over North America (Bachmeier et al., 1994; Merrill et al., 1996; Brioude et al., 2006; Cooper et al., 2006; Thompson et al., 2007). During the BAQS-Met campaign in the summer of 2007, a number of significant ozone enhancements in the troposphere were observed over Harrow, Ontario, resulting from stratospheric intrusion events. This interpretation is supported by twice-daily ozonesonde observations, surface ozone data, radar windprofiler data and geostatistical interpolation results of satellite ozone data from TES and AIRS, as well as modeling results from GEM-FLEXPART and AURAMS. A case study is presented that employs satellite observations as a low-resolution surrogate for ozonesonde observations, when the latter are not available for model evaluation. Under favourable conditions, they appear to be capable of detecting large stratospheric intrusions. The combined analysis shows that the different measurements and model results are consistent with each other, and provide a consistent picture of the behaviour and significance of stratospheric ozone intrusions over southwestern Ontario during the BAQS-Met campaign in the summer of 2007.

Stratospheric intrusions are important to the ozone budget of the mid-latitude troposphere, even in the summer. They appear to be responsible for much of the variability of ozone in the free troposphere at mid-latitudes. A calculation based on a profile-by-profile comparison indicates that $9 \%$ of the variance in the lower troposphere and $17 \%$ in the upper troposphere is due to stratospheric intrusions, but this is undoubtedly an underestimate, since it does not take into account errors in the modeled altitude or time of arrival of intrusions. Similar patterns of variability in the observations and GEM-FLEXPART results suggests that in fact, most of the variance in the upper troposphere is due to variable stratospheric input.

Such pattern comparison, as well as detailed comparison of individual profiles, argues that FLEXPART driven by GEM reproduces intrusion events with some skill, implying that GEM dynamics are modeling them fairly well, at least qualitatively. There are often important differences in the quantitative comparison, between the modeled intrusion and that seen in the observations, but it is not clear if this results from errors in some of the trajectories (each modeled intrusion is a sum of many FLEXPART trajectories), from the representation of ozone by $\mathrm{PV}$, or from errors in the actual GEM input fields. Sub-grid scale processes (e.g. convection, turbulence and waves) may also be important to cross-tropopause transport and might not be well captured by parameterizations. In the planetary boundary layer, complex dispersion and turbulence tends to render trajectories less representative of the actual flow (Stohl and Seibert, 1997).

With these caveats, we note that GEM-FLEXPART calculations indicate that stratospheric ozone intrusions contributed significantly to surface ozone on 26, 29-30 June and 1 July, and that, averaged over the BAQS-Met campaign, about $26 \%$ of ozone in the upper/middle troposphere, about $10 \%$ of ozone in the lowermost troposphere, and about $8 \%$ of ozone in the boundary layer was of stratospheric origin. These results suggest that stratospheric ozone made a moderate but significant contribution to the tropospheric ozone budget.

The AURAMS performance in the free troposphere is a dramatic improvement over previous versions without a stratospheric ozone tracer (Tarasick et al., 2007), although it now appears to bring down too much ozone in individual intrusions. This is very likely due to the model's coarse vertical resolution above $2 \mathrm{~km}$, particularly the poor vertical resolution around the tropopause. It seems likely that an improvement in the vertical coordinate would greatly improve the model's performance at representing stratospheretroposphere exchange events. A version of GEM incorporating AURAMS chemistry in-line is currently being tested at Environment Canada, and this (since it uses GEM's vertical coordinate) may be expected to perform very well in this regard.

Acknowledgements. This work was supported by funding from the Canadian Foundation for Climate and Atmospheric Sciences (CFCAS). The Harrow radar was installed with support from the Canada Innovation Foundation and Ontario Innovation Trust. We thank Jonathan Davies, Rad Sakura and Ildiko Beres for ozone launch support. We thank members of the TES team and AIRS teams for their measurements and data products.

Edited by: J. W. Bottenheim 


\section{References}

Allen, D. J., Dibb, J. E., Ridley, B., Pickering, K. E., and Talbot, R. W.: An estimate of the stratospheric contribution to springtime tropospheric ozone maxima using TOPSE measurements and beryllium-7 simulations, J. Geophys. Res., 108(D4), 8355, doi:101029/2001JD001428, 2003.

Appenzeller, C. and Davies, H. C.: Structure of stratospheric intrusions into the troposphere, Nature, 358, 570-572, doi:10.1038/358570a0, 13 August 1992.

Appenzeller, C., Holton, J. R., and Rosenlof, K. H.: Seasonal variation of mass transport across the tropopause, J. Geophys. Res., 101(D10), 15071-15078, doi:10.1029/96JD00821, 1996.

Bachmeier, A., Shipham, M., Browell, E., Grant, W., and Klassa, J.: Stratospheric/tropospheric exchange affecting the northern wetlands regions of Canada during summer 1990, J. Geophys. Res., 99(D1), 1793-1804, doi:10.1029/93JD02179, 1994.

Bayraktar, H. and Sezer Turalioglu, F.: A Kriging-based approach for locating a sampling site in the assessment of air quality, Stoch. Environ. Res. Risk Assess., (SERRA), 19(4), 301-305, doi:10.1007/s00477-005-0234-8, 2005.

Bazhanov, V. and Rodhe, H.: Tropospheric ozone at the Swedish mountain site Åreskutan: Budget and trends, J. Atmos. Chem., 28, 61-76, 1997.

Beekmann, M., Ancellet, G., Blonsky, S., De Muer, D., Ebel, A., Elbern, H., Hendricks, J., Kowol, J., Mancier, C., Sladkovic, R., Smit, H. G. J., Speth, P., Trickl, T., and Van Haver, Ph.: Regional and global tropopause fold occurrence and related ozone flux across the tropopause, J. Atmos. Chem., 28, 29-44, 1997.

Beer, R.: TES on the Aura mission: Scientific objectives, measurements, and analysis overview, IEEE Trans. Geosci. Remote Sens., 44, 1102-1105, 2006.

Beer, R., Glavich, T. A., and Rider D. M.: Tropospheric Emission Spectrometer for the Earth Observing System Aura satellite, Appl. Opt., 40, 2356-2367, 2001.

Bian, J., Gettelman, A., Chen, H., and Pan, L. L.: Validation of satellite ozone profile retrievals using Beijing ozonesonde data, J. Geophys. Res., 112, D06305, doi:10.1029/2006JD007502, 2007.

Bonasoni, P., Evangelisti, F., Bonafé, U., Ravegnani, F., Calzolari, F., Stohl, A., Tositti, L., Tubertini, O., and Colombo, T.: Stratospheric ozone intrusion episodes recorded at Mt. Cimone during the VOTALP project: case studies, Atmos. Environ., 34, 13551365, 2000.

Bourqui, M. S. and Trepanier, P.-Y.: Descent of deep stratospheric intrusions during the IONS August 2006 campaign, J. Geophys. Res., 115, D18301, doi:10.1029/2009JD013183, 2010.

Boxe, C. S., Worden, J. R., Bowman, K. W., Kulawik, S. S., Neu, J. L., Ford, W. C., Osterman, G. B., Herman, R. L., Eldering, A., Tarasick, D. W., Thompson, A. M., Doughty, D. C., Hoffmann, M. R., and Oltmans, S. J.: Validation of northern latitude Tropospheric Emission Spectrometer stare ozone profiles with ARCIONS sondes during ARCTAS: sensitivity, bias and error analysis, Atmos. Chem. Phys., 10, 9901-9914, doi:10.5194/acp-109901-2010, 2010.

Brioude, J., Cammas, J.-P., and Cooper, O. R.: Stratospheretroposphere exchange in a summertime extratropical low: analysis, Atmos. Chem. Phys., 6, 2337-2353, doi:10.5194/acp-62337-2006, 2006.

Browell, E. V., Fenn, M. A., Butler, C. F., Grant, W. B., Harriss, R. C., and Shipman, M. C.: Ozone and aerosol distributions in the summertime troposphere over Canada, J. Geophys. Res., 99, 1739-1755, 1994.

Browell, E. V., Hair, J. W., Butler, C. F., Grant, W. B., DeYoung, R. J., Fenn, M. A., Brackett, V. G., Clayton, M. B., Brasseur, L. A., Harper, D. B., Ridley, B. A., Konecki, A. A., Hess, P. G., Emmons, L. K., Tie, X., Atlas, E. L., Cantrell, C. A., Wimmers, A. J., Blake, D. R., Coffey, M. T., Hannigan, J. W., Dibb, J. E., Talbot, R. W., Flocke, F., Weinheimer, A. J., Fried, A., Wert, B., Snow, J. A., and Lefer, B. L.: Ozone, aerosol, potential vorticity, and trace gas trends observed at high-latitudes over North America from February to May 2000, J. Geophys. Res., 108(D4), 8369, doi:10.1029/2001JD001390, 2003.

CEP (2003), Carolina Environmental Program, Sparse Matrix Operator Kernel Emission (SMOKE) modelling system, University of North Carolina, Carolina Environmental Programs, Chapel Hill, NC, available online at: http://www.smoke-model.org/index. cfm.

Cho, S., Makar, P. A., Lee, W. S., Herage, T., Liggio, J., Li, S. M., Wiens, B., and Graham L.: Evaluation of a unified regional airquality modeling system (AURAMS) using PrAIRie2005 field study data: The effects of emissions data accuracy on particle sulphate predictions, Atmos. Environ., 43, 1864-1877, 2009.

Colette, A. and Ancellet, G.: Impact of vertical transport processes on the tropospheric ozone layering above Europe. Part II: Climatological analysis of the past 30 years, Atmos. Environ., 39, 5423-5435, doi:10.1016/j.atmosenv.2005.06.015, 2005.

Cooper, O. R., Forster, C., Parrish, D., Dunlea, E., Habler, G., Fehsenfeld, F., Holloway, J., Oltmans, S., Johnson, B., Wimmers, A., and Horowitz, L.: On the life-cycle of a stratospheric intrusion and its dispersion into polluted warm conveyor belts, J. Geophys. Res., 109, D23S09, doi:10.1029/2003JD004006, 2004.

Cooper, O. R., Stohl, A., Hubler, G., Hsie, E. Y., Parrish, D. D., Tuck, A. F., Kiladis, G. N., Oltmans, S. J., Johnson, B. J., Shapiro, M., Moody, J. L., and Lefohn, A. S.: Direct transport of midlatitude stratospheric ozone into the lower troposphere and marine boundary layer of the tropical Pacific Ocean, J. Geophys. Res., 110, D23310, doi:10.1029/2005JD005783, 2005.

Cooper, O. R., Stohl, A., Trainer, M., Thompson, A., Witte, J. C., Oltmans, S. J., Johnson, B. J., Merrill, J., Moody, J. L., Tarasick, D., Nédélec, P., Forbes, G., Newchurch, M. J., Schmidlin, F. J., Johnson, B. J., Turquety, S., Baughcum, S. L., Ren, X., Fehsenfeld, F. C., Meagher, J. F., Spichtinger, N., Brown, C. C., McKeen, S. A., McDermid, I. S., and Leblanc, T.: Large upper tropospheric ozone enhancements above mid-latitude North America during summer: In situ evidence from the IONS and MOZAIC ozone monitoring network, J. Geophys. Res., 111, D24S05, doi:10.1029/2006JD007306, 2006.

Côté, J., Gravel, S., Méthot, A., Patoine, A., and Roch, M.: The operational CMC-MRB Global Environmental Multiscale (GEM) model, part I: Design considerations and formulation, Mon. Weather Rev., 126(6), 1373-1395, 1998.

Cristofanelli, P., Bonasoni, P., Collins, W., Feichter, J., Forster, C., James, P., Kentarchos, A., Kubik, P. W., Land, C., Meloen, J., Roelofs, G. J., Siegmund, P., Sprenger, M., Schnabel, C., Stohl, A., Tobler, L., Tositti, L., Trickl, T., and Zanis, P.: Stratosphere-to-troposphere transport: A model and method evaluation, STACCATO special section of J. Geophys. Res., 108, 8525, doi:10.1029/2002JD002600, 2003.

Davies, T. D. and Schuepbach, E.: Episodes of high ozone concen- 
trations at the earth's surface resulting from transport down from the upper troposphere/lower stratosphere: a review and case studies, Atmos. Environ., 28(1), 53-68, 1994.

Dibb, J. E., Meeker, L. D., Finkel, R. C., Southon, J. R., Caffee, M. W., and Barrie, L. A.: Estimation of stratospheric input to the Arctic troposphere: ${ }^{7} \mathrm{Be}$ and ${ }^{10} \mathrm{Be}$ aerosols at Alert, Canada, J. Geophys. Res., 99, 12855-12864, 1994.

Dibb, J. E., Talbot, R. W., Lefer, B. L., Scheuer, E., Gregory, G. L., Browell, E. V., Bradshaw, J. D., Sandholm, S. T., and Singh, H. B.: Distributions of beryllium 7 and lead 210, and soluble aerosol-associated ionic species over the western Pacific: PEM West B, February-March 1994, J. Geophys. Res., 102, $28287-$ 28302, 1997.

Dibb, J. E., Talbot, R. W., Scheuer, E., Seid, G., DeBell, L., Lefer, B. L., and Ridley, B.: Stratospheric influence on the northern North American free troposphere during TOPSE: ${ }^{7} \mathrm{Be}$ as a stratospheric tracer, J. Geophys. Res., 108(D4), 8363, doi:10.1029/2001JD001347, 2003.

Divakarla, M., Barnet, C., Goldberg, M., Maddy, E., Irion, F., Newchurch, M., Liu, X., Wolf, W., Flynn, L., Labow, G., Xiong, X., Wei, J., and Zhou, L.: Evaluation of Atmospheric Infrared Sounder ozone profiles and total ozone retrievals with matched ozonesonde measurements, ECMWF ozone data, and Ozone Monitoring Instrument retrievals, J. Geophys. Res., 113, D15308, doi:10.1029/2007JD009317, 2008.

Elbern, H., Kowol, J., Sladkovic, R., and Ebel, A.: Deep stratospheric intrusions: A statistical assessment with model guided analysis, Atmospheric Environment, 31, No. 19, 3207-3226, 1997.

Emanuel, K. A. and Zivkovie-Rothman, M.: Development and evaluation of a convection scheme for use in climate models, J. Atmos. Sci., 56, 1766-1782, 1999.

Fetzer, E. J., Lambrigtsen, B. H., Eldering, A., Aumann, H. H., and Chahine, M. T.: Biases in total precipitable water vapor climatologies from Atmospheric Infrared Sounder and Advanced Microwave Scanning Radiometer, J. Geophys. Res., 111, D09S16, doi:10.1029/2005JD006598, 2006.

Gage, K. S., Ecklund, W. L., Riddle, A. C., and Balsley, B. B.: Objective tropopause height determination using low-resolution VHF radar observations, J. Atmos. Ocean. Tech., 3, 248-254, 1986.

Gong, W., Dastoor, A. P., Bouchet, V. S., Gong, S., Makar, P. A., Moran, M. D., Pabla, B., Ménard, S., Crevier, L.-P., Cousineau, S., and Venkatesh, S.: Cloud processing of gases and aerosols in a regional air quality model (AURAMS), Atmos. Res., 82, 248$275,2006$.

Hocking, W. K.: System design, signal-processing procedures, and preliminary results for the Canadian (London, Ontario) VHF atmospheric radar, Rad. Sci., 32(2), 687-706, 1997.

Hocking, W. K., Carey-Smith, T. K., Tarasick, D. W., Argall, P. S., Strong, K., Rochon, Y., Zawadzki, I., and Taylor, P. A.: Detection of stratospheric ozone intrusion by windprofiler radars, Nature, 450(7167), 281-284, doi:10.1038/nature06312, 2007.

Holton, J. R., Haynes, P. H., McIntyre, M. E., Douglas, A. R., Rood, R. B., and Pfister, L.: Stratosphere-troposphere exchange, Rev. Geophys, 33, 403-439, 1995.

Hooper, D. A. and Arvelius, J.: Monitoring of the Arctic winter tropopause: A comparison of radiosonde, ozondesonde and MST radar observations, in Proc. MST9-COST76, edited by: Ed- wards, B., 385-388. SCOSTEP and Meteo France, 2000.

Houyoux, M. R., Vukovich, J. M., Coats Jr., C. J., and Wheeler, N. J. M.: Emission inventory development and processing for the Seasonal Model for Regional Air Quality (SMRAQ) project, J. Geophys. Res., 105, 9079-9090, 2000.

James, P., Stohl, A., Forster, C., Eckhardt, S., Seibert, P., and Frank, A.: A 15-year climatology of stratosphere-troposphere exchange with a Lagrangian particle dispersion model: 2. Mean climate and seasonal variability, STACCATO special section of J. Geophys. Res., 108, 8522, doi:10.1029/2002JD002639, 2003 a.

James, P., Stohl, A., Forster, C., Eckhardt, S., Seibert, P., and Frank, A.: A 15-year climatology of stratosphere-troposphere exchange with a Lagrangian particle dispersion model: 1. Methodology and validation, STACCATO special section of J. Geophys. Res., 108, 8519, doi:10.1029/2002JD002637, 2003 b.

Johnson, W. B. and Viezee, W.: Stratospheric ozone in the lower troposphere. I - Presentation and interpretation of aircraft measurements, Atmos. Environ., 15(7), 1309-1323, doi:10.1016/0004-6981(81)90325-5, 1981.

Kulawik, S. S., Worden, H., Osterman, G., Luo, M., Beer, R., Kinnison, D., Bowman, K. W., Worden, J., Eldering, A., Lampel, M., Steck, T., and Rodgers, C. D.: TES atmospheric profile retrieval characterization: an orbit of simulated observations, IEEE Trans. Geosci. Remote Sens., 44, 1324-1333, 2006.

Lefohn, A. S., Oltmans, S. J., Dann, T., and Singh, H. B.: Presentday variability of background ozone in the lower troposphere, J. Geophys. Res., 106, 9945-9958, doi:10.1029/2000JD900793, 2001.

Li, Q., Jacob, D. J., Fairlie, T. D., Liu, H., Martin, R. V., and Yantosca, R. M.: Stratospheric versus pollution influences on ozone at Bermuda: Reconciling past analyses, J. Geophys. Res., 107(D22), 4611, doi:10.1029/2002JD002138, 2002.

Liu, G., Tarasick, D. W., Fioletov, V. E., Sioris, C. E., and Rochon, Y. J.: Ozone correlation lengths and measurement uncertainties from analysis of historical ozonesonde data in North America and Europe, J. Geophys. Res., 114, D04112, doi:10.1029/2008JD010576, 2009.

Logan, J. A.: An analysis of ozonesonde data for the troposphere: Recommendatioins for testing 3-D models, and development of a gridded climatology for tropospheric ozone, J. Geophys. Res., 104, 16115-16149, 1999.

Makar, P. A., Moran, M. D., Zheng, Q., Cousineau, S., Sassi, M., Duhamel, A., Besner, M., Davignon, D., Crevier, L.-P., and Bouchet, V. S.: Modelling the impacts of ammonia emissions reductions on North American air quality, Atmos. Chem. Phys., 9, 7183-7212, doi:10.5194/acp-9-7183-2009, 2009.

Makar, P. A., Zhang, J., Gong, W., Stroud, C., Sills, D., Hayden, K. L., Brook, J., Levy, I., Mihele, C., Moran, M. D., Tarasick, D. W., and He, H.: Mass tracking for chemical analysis: the causes of ozone formation in southern Ontario during BAQS-Met 2007, Atmos. Chem. Phys., 10, 11151-11173, doi:10.5194/acpd10-11151-2010, 2010a.

Makar, P. A., Gong, W., Mooney, C., Zhang, J., Davignon, D., Samaali, M., Moran, M. D., He, H., Tarasick, D. W., Sills, D., and Chen, J.: Dynamic adjustment of climatological ozone boundary conditions for air-quality forecasts, Atmos. Chem. Phys., 10, 8997-9015, doi:10.5194/acp-10-8997-2010, 2010 b.

Mauzerall, D. L., Jacob, D. J., Fan, S. M., Bradshaw, J. D., Gregory, G. L., Sachse, G. W., and D. R. Blake: Origins of tropospheric 
ozone at remote high northern latitudes in summer, J. Geophys. Res., 101, 4175-4188, 1996.

Meloen, J., Siegmund, P., van Velthoven, P., Kelder, H., Sprenger, M., Wernli, H., Kentarchos, A., Roelofs, G., Feichter, J., Land, C., Forster, C., James, P., Stohl, A., Collins, W., and Cristofanelli, P.: Stratosphere troposphere exchange: a model and method intercomparison, STACCATO special section of J. Geophys. Res., 108, 8526, doi:10.1029/2002JD002274, 2003.

Merrill, J., Moody, J., Oltmans, S., and Levy II, H.: Meteorological analysis of tropospheric ozone profiles at Bermuda, J. Geophys. Res., 101(D22), 29201-29211, 1996.

Monahan, K. P., Pan, L. L., McDonald, A., Bodeker, G. E., Wei, J. C., George, S., Barnet, C., and Maddy, E. S.: Validation of AIRS v4 ozone profiles in the UTLS using ozonesondes from Lauder, NZ and Boulder, USA, J. Geophys. Res., 112, D17304, doi:10.1029/2006JD008181, 2007.

Moody, J. L., Oltmans, S. J., Levy II, H., and Merrill, J. T.: Transport climatology of tropospheric ozone: Bermuda, 1988-1991, J. Geophys. Res., 100(D4), 7179-7194, doi:10.1029/94JD02830, 1995.

Nassar, R., Logan, J. A., Worden, H. M., Megretskaia, I. A., Bowman, K. W., Osterman, G. B., Thompson, A. M., Tarasick, D. W., Austin, S., Claude, H., Dubey, M. K., Hocking, W. K., Johnson, B. J., Joseph, E., Merrill, J., Morris, G. A., Newchurch, M., Oltmans, S. J., Posny F., Schmidlin, F. J., Whiteman, D. N., and Witte, J. C.: Validation of Tropospheric Emission Spectrometer (TES) nadir ozone profiles using ozonesonde measurements, J. Geophys. Res., 113, D15S17, doi:10.1029/2007JD008819, 2008.

Olsen E. T.: Editor, AIRS version 5 release level 2 standard product quickstart, AIRS Data Document, available online at: http://disc. sci.gsfc.nasa.gov/AIRS/documentation, 2007a.

Olsen, E. T.: Editor, AIRS/AMSU/HSB version 5 changes from verstion 4, AIRS Data Document, available online at: http://disc. sci.gsfc.nasa.gov/AIRS/documentation, 2007b.

Oltmans, S. J., Raatz, W. E., and Komhyr, W. D.: On the transfer of stratospheric ozone into the troposphere near the north pole, J. Atmos. Chem., 9, 245-253, 1989.

Osterman, G. B.: Editor, TES level 2 algorithm theoretical basis document, Version 1.99, JPLD-16474. http://tes.jpl.nasa.gov/ uploadedfiles/TES.ATBD.L2.V1.99.v10.pdf, 2004.

Pan, L. L., Bowman, K. P., Shapiro, M., Randel, W. J., Gao R. S., Campos, T., Davis, C., Schauffler, S., Ridley, B. A., Wei, J. C., and Barnet, C.: Chemical behavior of the tropopause observed during the Stratosphere-Troposphere Analyses of Regional Transport experiment, J. Geophys. Res., 112, D18110, doi:10.1029/2007JD008645, 2007.

Parrington, M., Jones, D. B. A., Bowman, K. W., Horowitz, L. W., Thompson, A. M., Tarasick, D. W., and Witte, J. C.: Estimating the summertime tropospheric ozone distribution over North America through assimilation of observations from the Tropospheric Emission Spectrometer, J. Geophys. Res., 113, D18307, doi:10.1029/2007JD009341, 2008.

Seibert, P., Kruger, B., and Frank, A.: Parameterisation of convective mixing in a Lagrangian particle dispersion model, paper presented at 5th GLOREAM Workshop, Paul Scherrer Inst., Wengen, Switzerland, 24-26 September, 2001.

Singh, H. B., Viezee, W., Johnson, W. B., and Ludwig, F. L.: The impact of stratospheric ozone on tropospheric air quality, J. Air
Pollut. Control Ass., 30, 1009-1017, 1980.

Smit, H. G. J., Straeter, W., Johnson, B., Oltmans, S., Davies, J., Tarasick, D. W., Hoegger, B., Stubi, R., Schmidlin, F., Northam, T., Thompson, A., Witte, J., Boyd, I., and Posny, F.: Assessment of the performance of ECC-ozonesondes under quasi-flight conditions in the environmental simulation chamber: Insights from the Juelich Ozone Sonde Intercomparison Experiment (JOSIE), J. Geophys Res., 112, D19306, doi:10.1029/2006JD007308, 2007.

Smyth, S. C., Jiang, W., Roth, H., Moran, M. D., Makar, P. A., Yang, F., Bouchet, V. S., and Landry, H.: A comparative performance evaluation of the AURAMS and CMAQ air quality modelling systems. Atmos. Environ., 43, 1059-1070, 2009.

Sprenger, M. and Wernli, H.: A northern hemispheric climatology of cross-tropopause exchange for the ERA15 time period (1979-1993), J. Geophys. Res., 108(D12), 8521, doi:10.1029/2002JD002636, 2003.

Stein, A., wan der Meer, F., and Gorte, B. (Eds.): Spatial statistics for remote sensing, Kluwer Academic Publishers, 2002.

Stevenson, D. S., Dentener, F. J., Schultz, M. G., Ellingsen, K., van Noije, T. P. C., Wild, O., Zeng, G., Amann, M., Atherton, C. S., Bell, N., Bergmann, D. J., Bey, I., Butler, T., Cofala, J., Collins, W. J., Derwent, R. G., Doherty, R. M., Drevet, J., Eskes, H. J., Fiore, A. M., Gauss, M., Hauglustaine, D. A., Horowitz, L. W., Isaksen,I. S. A., Krol, M. C., Lamarque, J.-F., Lawrence, M. G., Montanaro, V., Müller, J.-F., Pitari, G., Prather, M. J., Pyle, J. A., Rast, S., Rodriguez, J. M., Sanderson, M. G., Savage, N. H., Shindell, D. T., Strahan, S. E., Sudo, K., and Szopa, S.: Multimodel ensemble simulations of present-day and near future tropospheric ozone, J. Geophys. Res., 111, D08301, doi:10.1029/2005JD006338, 2006.

Stohl, A. and Seibert, P.: Accuracy of trajectories as determined from the conservation of meteorological tracers, Q. J. Roy. Meteorol. Soc., 124 (549), 1465-1484, doi:10.1002/qj.49712454907, 1997.

Stohl, A. and Thomson, D. J.: A density correction for Lagrangian particle dispersion modles, Boud. Lay. Meteorol., 90, 155-167, 1999.

Stohl, A., Hittenberger, M., and Wotawa, G.: Validation of the Lagrangian particle dispersion model FLEXPART against large scale tracer experiment data, Atmos. Environ., 24, 4245-4264, 1998.

Stohl, A., Spichtinger-Rakowsky, N., Bonasoni, P., Feldmann, H., Memmesheimer, M., Scheel, H. E., Trickl, T., Hübener, S. H., Ringer, W., and Mandl, M.: The influence of stratospheric intrusions on alpine ozone concentrations, Atmos. Environ., 34, 1323-1354, 2000.

Stohl, A., Bonasoni, P., Cristofanelli, P., Collins, W., Feichter, J., Frank, A., Forster, C., Gerasopoulos, E., Gäggeler, H., James, P., Kentarchos, T., Kromp-Kolb, H., Krüger, B., Land, C., Meloen, J., Papayannis, A., Priller, A., Seibert, P., Sprenger, M., Roelofs, G. J., Scheel, H. E., Schnabel, C., Siegmund, P., Tobler, L., Trickl, T., Wernli, H., Wirth, V., Zanis, P., and Zerefos, C.: Stratosphere-troposphere exchange - a review, and what we have learned from STACCATO, STACCATO special section of J. Geophys. Res., 108, 8516, doi:10.1029/2002JD002490, 2003.

Stohl, A., Forster, C., Frank, A., Seibert, P., and Wotawa, G.: Technical note: The Lagrangian particle dispersion model FLEXPART version 6.2, Atmos. Chem. Phys., 5, 2461-2474, 
doi:10.5194/acp-5-2461-2005, 2005.

Tang, Y., Carmichael, G. R., Thongboonchoo, N., Chai, T., Horowitz, L. W., Pierce, R. B., Al-Saadi, J. A., Pfister, G., Vukovich, J. M., Avery, M. A., Sachse, G. W., Ryerson, T. B., Holloway, J. S., Atlas, E. L., Flocke, F. M., Weber, R. J., Huey, L. G., Dibb, J. E., Streets, D. G., and Brune, W. H.: Influence of lateral and top boundary conditions on regional air quality prediction: A Multiscale study coupling regional and global chemical transport models, J. Geophys. Res., 112, D10S18, doi:10.1029/2006JD007515, 2007.

Tarasick, D. W. and Slater, R.: Ozone in the troposphere: Measurements, climatology, budget, and trends, Atmos. Ocean, 46, 93-115, doi:10.3137/ao.460105, 2008.

Tarasick, D. W., Moran, M. D., Thompson, A. M., Carey-Smith, T., Rochon, Y., Bouchet, V. S., Gong, W., Makar, P. A., Stroud, C., Ménard, S., Crevier, L.-P., Cousineau, S., Pudykiewicz, J. A., Kallaur, A., Moffet, R., Ménard, R., Robichaud, A., Cooper, O. R., Oltmans, S. J., Witte, J. C., Forbes, G., Johnson, B. J., Merrill, J., Moody, J. L., Morris, G., Newchurch, M. J., Schmidlin, F. J., and Joseph, E.: Comparison of Canadian air quality forecast models with tropospheric ozone profile measurements above midlatitude North America during the IONS/ICARTT campaign: evidence for stratospheric input, J. Geophys. Res., 112, D12S22, doi:10.1029/2006JD007782, 2007.

Thompson, A. M., Stone, J. B., Witte, J. C., Miller, S., Oltmans, S. J., Kucsera, T. L., Merrill, J. T., Forbes, G., Tarasick, D. W., Joseph, E., Schmidlin, F. J., MacMillan, W. W., Warner, J., Hintsa, E., and Johnson, J.: Intercontinental chemical transport experiment ozonesonde network study (IONS) 2004: 2. Tropospheric ozone budgets and variability over northeastern North America, J. Geophys. Res., 112, D12S13, doi:10.1029/2006JD007670, 2007.

Thompson, A. M., Oltmans, S. J., Tarasick, D. W., Von der Gathen, P., Smit, H. G. J., and Witte, J. C.: Strategic ozone sounding networks: Review of design and accomplishments, Atmos. Environ., ISSN 1352-2310, doi:10.1016/j.atmosenv.2010.05.002, 2010.

Tong, D. Q. and Mauzerall, D. L.: Spatial variability of summertime tropospheric ozone over the continental United States: implications of an evaluation of the CMAQ model, Atmos. Environ., 40, 3041-3056, 2006.
Tranchant, B. J. S. and Vincent, A. P.: Statistical interpolation of ozone measurements from satellite data (TOMS, SBUV and SAGE II) using the kriging method, Ann. Geophys., 18, 666678, doi:10.1007/s00585-000-0666-x, 2000.

Vaughan, G., Howells, A., and Price, J. D.: Use of MST radars to probe the mesoscale structure of the tropopause, Tellus, 47A, 759-765, 1995.

Wakamatsu, S., Uno, I., Ueda, H., and Uehara, K.: Observational study of stratospheric ozone intrusions into the lower troposphere, Atmos. Environ., 23(8), 1815-1826, 1989.

Williams, E. J., F. C. Fehsenfeld, B. T. Jobson, W. C. Kuster, P. D. Goldan, J. Stutz and W. A. McClenny (), Comparison of ultraviolet absorbance, chemiluminescence, and DOAS instruments for ambient ozone monitoring. Environ. Sci. Technol., 40(18), 5755-5762, 2006.

Wimmers, A. J. and Moody, J. L.: Tropopause folding at satellite-observed spatial gradients: 1. Verification of an empirical relationship, J. Geophys. Res., 109, D19306, doi:10.1029/2003JD004145, 2004.

Worden, J., Sund-Kulawik, S., Shephard, M. W., Clough, S. A., Worden, H., Bowman, K., and Goldman, A.: Predicted errors of tropospheric emission spectrometer nadir retrievals from spectral window selection, J. Geophys. Res., 109(D9), D09308, doi:10.1029/2004JD004522, 2004.

Worden, J., Liu, X., Bowman, K., Chance, K., Beer, R., Eldering, A., Gunson, M., and Worden, H.: Improved tropospheric ozone profile retrievals using OMI and TES radiances. Geophys. Res. Lett., 34, L01809, doi:10.1029/2006GL027806, 2007.

WMO: International meteorological vocabulary. WMO, No. 182, TP. 91, Geneva Secretariat of the World Meteorological Organization, p. xvi, 276, 1966.

Zanis, P., Trickl, T., Stohl, A., Wernli, H., Cooper, O., Zerefos, C., Gaggeler, H., Tobler, L., Kubik, P. W., Priller, A., Scheel, H. E., Kanter, H. J., Cristofanelli, P., Forster, C., James, P., Gerasopoulos, E., Delcloo, A., Papayannis, A., and Claude, H.: Forecast, observation and modelling of a deep stratospheric intrusion event over Europe, Atmos. Chem. Phys., 3, 763-777, doi:10.5194/acp3-763-2003, 2003. 